\section{Evaluating short term simulations of a forest stand invaded by emerald ash borer}

\author{
Abe Levin-Nielsen, Lynne K Rieske
}

The invasive emerald ash borer (Agrilus planipennis - EAB) is causing rapid and widespread ash (Fraxinus spp.) mortality in eastern North America, has established populations near Moscow, Russia, and is threatening ash resources in Europe. Given the prevalence of susceptible hosts these post-invasion forests will clearly differ from their pre-invasion counterparts. Understanding these changes is key to mitigating the impacts of invasion and developing sound management strategies. We evaluated short term changes in a forest stand invaded by EAB, and examined if the southern variant of the Forest Vegetation $\mathrm{Si}$ mulator (FVS) could accurately predict those changes. Through simulation, managers can gain a clearer understanding of how pest invasions impact and alter future forest dynamics. However, many simulators are designed to achieve long-term predictions and thus do not align with the short term changes associated with rapid EAB-induced ash mortality. Woody vegetation was surveyed in 2010 and used to project impacts of EAB invasion into 2012 by simulating a $50 \%$ ash mortality rate. The same plots were then re-surveyed in 2012 , allowing us to evaluate: (1) changes in actual forest composition and structure; and (2) simulation accuracy. Within our forest stand, FVS accurately estimated short term changes in stem density and basal area parameters, thus demonstrating its value as a short-term simulator for EAB-induced changes within the southern region of the United States. EAB-induced ash mortality is quickly changing these forests and will ultimately alter how stakeholders manage their lands. We discuss the potential usefulness of FVS as a tool for aiding management decisions in response to EAB invasion.

Keywords: Ash, Forest Succession, Modeling, Forest Vegetation Simulator

\section{Introduction}

Invasion by non-native species is a significant threat to forest health, natural resource management, and forest sustainability. Nonnative invasions threaten ecosystem function and native biodiversity, and have widespread economic impacts (Wilcove et al. 1998, Byers et al. 2002, Pimentel et al. 2005, Ehrenfeld 2010, Aukema et al. 2011). Forest ecosystems are often at the forefront of species invasions (Haack 2006, Aukema et al. 2011). In deciduous forests of eastern North America, ash (Fraxinus, Fam. Oleaceae) are currently under attack and suffering extensive mortality due to invasion by the exotic emerald ash borer (EAB - Agrilus planipennis; Coleoptera: Buprestidae). More recently EAB has become established near Moscow,
Russia, and is poised to invade and threaten ash resources throughout Europe (Straw et al. 2013)

Emerald ash borer is native to China and was first reported in North America in Michigan in 2002 (Haack et al. 2002). Larvae feed on phloem beneath the bark, forming serpentine galleries that disrupt water and nutrient flow to the canopy, ultimately girdling the tree (Cappaert et al. 2005, Flower et al. 2013b). Mortality occurs quickly; infested trees can die within 6 years (Knight et al. 2013). In North America, initial eradication attempts failed and infestations spread rapidly. Range expansion has been aided by long distance movement of firewood and other infested materials (Cappaert et al. 2005). EAB is currently reported in the majority of east- $\square$ Department of Entomology, University of Kentucky, S-225 Agricultural Science Center North, 40546-0091 Lexington, KY (USA)

@ Lynne K Rieske (lynne.rieske-kinney@uky.edu)

Received: Oct 23, 2013 - Accepted: Apr 02, 2014

Citation: Levin-Nielsen A, Rieske LK, 2015. Evaluating short term simulations of a forest stand invaded by emerald ash borer. iForest 8: 19-24 [online 2014-05-26] URL:

http://www.sisef.it/iforest/contents/?id=ifor1163-007

Communicated by: Massimo Faccoli ern USA states (Emeraldashborer.info 2014), and it will likely become pervasive wherever Fraxinus occurs. Among the North American ash species tested, all are susceptible to emerald ash borer (Rebek et al. 2008, Cappaert et al. 2005), though regional variation in susceptibility is evident among the dominant species (Anulewicz et al. 2007, Tanis \& McCullough 2012).

The genus Fraxinus is widely distributed in North America and forms a significant component of eastern deciduous forests (Burns \& Honkala 1990). Among the most common species is white ash ( $F$. americana $\mathrm{L}$.); it rarely occurs as a dominant, but grows most often in association with oak (Quercus spp.), maple (Acer spp.), birch (Betula spp.), and beech (Fagus grandifolia Ehrh. - Schlesinger 1990). White ash grows best on welldrained, calcareous soils. It is an excellent commercial hardwood providing a strong, pliable, and shock resistant wood, with a variety of uses (Wharton \& Barbour 1973, Schlesinger 1990). Similarly green ash $(F$. pennsylvanica Marsh.) is also widely distributed, but occurs most often in bottom lands on moist, well drained soils, co-occurring with box elder ( $A$. negundo L.), pecan ( $\mathrm{Ca}$ rya illinoensis (Wangenh.) K. Koch), sweetgum (Liquidambar styraciflua L.), and American elm (Ulmus americana L. - Kennedy 1990). Its wood shares many of the characteristics of white ash (Kennedy 1990). Because they thrive in a variety of habitats and are resistant to most insects and diseases, green ash are utilized extensively in urban forests, green spaces, park lands, landscapes, and as street trees (Burns \& Honkala 1990). Blue ash ( $F$. quadrangulata Michx.) has a limited distribution and occurs on limestone outcrops of the Inner Bluegrass region of Kentucky (Wharton \& Barbour 1973). Along with white ash, bur, and chinkapin oaks (Q. macrocarpa Michx. and Q. muehlenbergii Engelm.), blue ash is a major component of savanna forests of the Bluegrass region.

In addition to their economic significance, ash trees are also ecologically significant. Ash are prolific seed producers; these seeds are an important food source for wildlife (Martin et al. 1961), but ash seedling regeneration ends quickly following EAB-induced ash mortality because of the depleted seed bank (Klooster et al. 2014). Ash also provide food and cover for wildlife (Faanes 1984) and some arthropods are ash-dependent (Gandhi \& Herms 2010b). Ash also contribute to nutrient cycling within hardwood forests (Reiners \& Reiners 1970). The contributions, integrity and sustainability of ash and its associates are threatened by the emerald ash borer invasion.

Without proactive management, the emerald ash borer could extirpate ash from North 


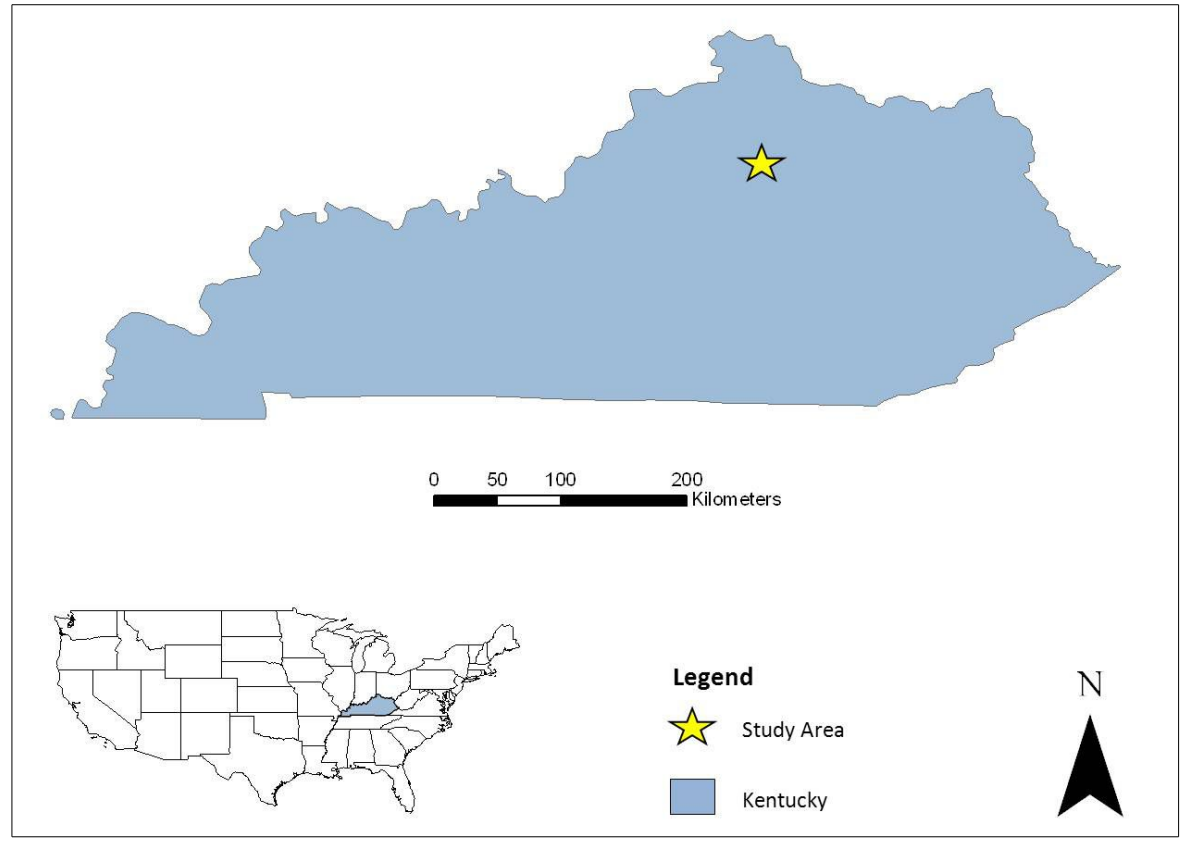

Fig. 1 - Location of study area within Kentucky (USA).

American forests and urban areas. Ash decline will influence ecological interactions, such as potential shifts in bark-foraging and other bird behaviors (Flower et al. 2014), and alter forest dynamics by creating canopy gaps that ultimately change forest composition and impact successional dynamics. In the USA Midwest, Acer and Ulmus species have the highest relative growth rates following EAB-induced ash mortality (Flower et al. 2013a). Large scale loss of ash has the potential to impact regional carbon storage by reducing net primary productivity within high ash density forests (Flower et al. 2013a).

Given the rapid and extensive dispersal of emerald ash borer through the eastern USA and Canada, the devastating and widespread mortality of ash left in its wake, and the extent of suitable host material remaining, the continuing invasion of EAB will change the nature of our forests. Post-invasion forests in the USA and elsewhere will clearly differ in composition and structure from their pre-invasion counterparts. As the invasion progresses, tools are needed to help managers gain a clearer understanding of the extent and magnitude of these differences, so that protocols can be developed to help minimize their impacts. Such tools would facilitate the decision process by giving managers the ability to simulate future forest dynamics based on potential management options chosen by the user.

The Forest Vegetation Simulator (FVS) is an individual tree growth and yield model that simulates future forest stand dynamics up to 50 years (Dixon 2002). FVS is calibrated by using models that incorporate Forest
Inventory and Analysis data to develop tree growth, mortality, and volume equations, and is adjusted by using local growth rates to tailor model projections to their respective geographic regions. Natural resource managers in the USA can simulate the effects of management practices and disturbances on stand structure and composition using region-specific variants. FVS can predict losses from fire and insect outbreaks by incorporating component files and extensions developed to simulate specific disturbances, and it can be adapted to simulate impacts to forest structure and composition caused by invasive pests (Bao et al. 2008, Spaulding \& Rieske 2010, 2011).

FVS has been widely used to analyze long term changes in forest dynamics. However, these long-term predictions do not align with the short-term impacts associated with rapid EAB-induced ash mortality. We argue that simulating these short-term changes would be a useful tool for managers and that FVS could be an important platform for analyzing potential management strategies. Therefore our objective was to evaluate short term changes in a forest stand invaded by EAB, and evaluate whether the southern variant of FVS could accurately predict those changes. We assessed forest composition and structure in pre-impacted forests of central Kentucky (USA) and again two years following initial signs of invasion to compare shortterm changes following EAB establishment. We then compared our actual data to predictions generated by the southern variant of FVS, and discuss its usefulness as a tool for aiding management decisions in response to $\mathrm{EAB}$ invasion.

\section{Materials and methods}

\section{Initial vegetation assessment}

A single site was selected in 2010 in a private 13.8 ha forest in Franklin County, in the center of the initial EAB-infested region of Kentucky (Fig. 1), which now encompasses 27 counties (EAB 2014). Nine 0.04 ha fixedradius plots were established to survey woody vegetation and landscape characteristics. Plots were placed a minimum of $50 \mathrm{~m}$ apart and surveyed using the Common Stand Exam protocol (Anonymous 2003) of the USDA Forest Service's Natural Resource Information System: Field Sampled Vegetation Module. Subplots were used within each 0.04 ha whole plot to survey woody vegetation of different strata. Each whole plot contained five 0.004 ha subplots and five 0.0004 ha micro-plots. The first subplot was located at the whole plot center and the remaining four were positioned $7.7 \mathrm{~m}$ in each cardinal direction from the plot center. Micro-plots were then positioned in the center of each subplot. Within each whole plot, canopy and mid-story trees $(\geq 12.7 \mathrm{~cm} \mathrm{DBH})$ were identified to species, and diameter $1.4 \mathrm{~m}$ above ground level $(\mathrm{DBH})$, height, and crown height (distance from ground level to crown) was assessed. Trees and saplings $(<12.7 \mathrm{~cm}$ DBH and $>137 \mathrm{~cm}$ height) were recorded within the subplots, while seedlings and woody ground cover $(<137 \mathrm{~cm}$ height $)$ were measured in the micro-plots. Thus the surveyed site included nine 0.04 ha whole plots, forty-five 0.004 ha subplots, and forty-five 0.0004 ha micro-plots (Coleman et al. 2008, Adkins \& Rieske 2013). Diameter measurements were then used to determine basal area of the overstory vegetation within each whole plot (Spurr 1962). Stand structure (single story, two-storied, multi-storied, or mosaic), aspect, percent slope, slope position (ridgetop, shoulder, backslope, footslope, toeslope, or valley bottom), and elevation were recorded for each whole plot.

EAB was first reported in our study area in 2009 , though no signs were apparent in our initial 2010 survey. Following the initial survey, invading emerald ash borer populations became evident and the area experienced extensive EAB-induced mortality. The preestablishment vegetation data was used as a baseline to characterize changes in the woody plant community following emerald ash borer invasion, and also to evaluate the accuracy of FVS for modeling short term changes in stand dynamics.

\section{Post-establishment vegetation assessment}

Short term changes in woody vegetation were assessed by re-surveying in 2012 using the same Common Stand Exam protocol. Adult emerald ash borer exit holes were detected on ash stems throughout the study site 
and EAB-induced ash mortality was evident Changes in forest composition and structure were characterized by calculating abundance $\left(\right.$ stems $\left.\mathrm{ha}^{-1}\right)$ and basal area $\left(\mathrm{m}^{2} \mathrm{ha}^{-1}\right)$ within the upper and middle strata using whole and sub-plot data. Additionally, ash abundance and basal area were calculated to better quantify direct EAB-induced changes. Seedling regeneration was analyzed and reported by comparing changes in stem abundance within the 0.0004 ha micro-plots.

\section{Predictive modeling}

The southern variant of FVS is calibrated for the southern region of the USA using Forest Inventory and Analysis data from all 13 states of this region (Dixon 2002). It is most suited for Kentucky's forest types (Spaulding 2009), and was used to model EAB-induced ash mortality and to simulate changes in stand characteristics. The surveyed vegetation data used for the FVS model are categorized into either plot-level data or treelevel data. Plot-level data includes aspect, canopy structure, elevation, slope percent, and slope position, which are used to further adjust the model to site conditions. Tree-level data represents individual trees within plots, and include species identification, $\mathrm{DBH}$, height, and crown height.

Within the FVS interface the user controls how the data is analyzed. Keywords describe management treatments, compute variables, adjust model estimates, set the number of cycles, and the length of the simulation. FVS runs the model by first processing the keywords and reading the input data, and then applying thinning or user defined mortality. Specialized growth models are then run based on the regional variant and the requested variables are then generated (Dixon 2002)

The initial EAB infestation date was estimated as 2009, based upon a log section cut by Kentucky Division of Forestry personnel. To simulate EAB-induced ash mortality into 2012 a $50 \%$ mortality rate was applied to all ash $>3.81 \mathrm{~cm} \mathrm{DBH}$, based on average postinfestation mortality rates (Knight et al. 2013). We applied the ash mortality to the initial 2010 woody vegetation data in FVS to predict 2012 forest composition and structure. From these predictions, four basic stand parameters were calculated, including the number of ash stems, ash basal area, the total number of stems, and total basal area. To more accurately analyze the predictions within certain size classes, total stems and total basal area parameters were divided into either $>$ or $<12.7 \mathrm{~cm} \mathrm{DBH}$ for a total of 8 parameters in the model; seedling data were treated separately. The simulated 2012 parameters were used to represent the "predicted" 2012 data set. "Predicted" 2012 data was compared against "actual" 2012 field data to evaluate the rigor of the FVS simulations.
Tab. 1 - Comparison of woody vegetation in 0.04 ha forest plots $(n=9)$ in Franklin County, KY (USA) invaded by emerald ash borer. The column "2010 Actual" represents actual preinvasion conditions, "2012 Actual" represents actual 2 year post-invasion conditions, and "2012 Predicted" represents projected conditions 2 year post-invasion based on FVS simulations. Five of the eight parameters were different between 2010 actual and 2012 actual, directly demonstrating the impacts of the $\mathrm{EAB}$ invasion, while none of the parameters were different between 2012 actual and 2012 predicted, reflecting the accuracy of the FVS predictions.

\begin{tabular}{lccccc}
\hline Per hectare & $\begin{array}{c}\mathbf{2 0 1 0} \\
\text { Actual }\end{array}$ & $\begin{array}{c}\text { Wilcoxon } \\
\mathbf{S}_{\mathbf{8}}(\mathbf{P})\end{array}$ & $\begin{array}{c}\mathbf{2 0 1 2} \\
\text { Actual }\end{array}$ & $\begin{array}{c}\text { Wilcoxon } \\
\mathbf{S}_{\mathbf{8}}(\mathbf{P})\end{array}$ & $\begin{array}{c}\mathbf{2 0 1 2} \\
\text { Predicted }\end{array}$ \\
\hline Ash stems & 96.1 & $10.5(0.03)$ & 60.4 & $8.5(0.17)$ & 48 \\
Ash basal area & 10.4 & $16.5(0.05)$ & 6.3 & $5.5(0.57)$ & 5.4 \\
Total stems & 1367 & $-4.5(0.65)$ & 1442 & $8.5(0.36)$ & 1300 \\
Stems $>12.7 \mathrm{~cm} \mathrm{DBH}$ & 455.8 & $19.5(0.02)$ & 392.6 & $-7.5(0.43)$ & 406.4 \\
Stems $<12.7 \mathrm{~cm} \mathrm{DBH}$ & 911.6 & $-5.0(0.47)$ & 1048.8 & $11.5(0.20)$ & 893.2 \\
Total basal area & 34.2 & $19.5(0.02)$ & 28.5 & $-7.0(0.44)$ & 29.9 \\
Basal area $>12.7 \mathrm{~cm} \mathrm{DBH}$ & 32.4 & $20.5(0.01)$ & 26.8 & $-4.5(0.65)$ & 27.9 \\
Basal area $<12.7 \mathrm{~cm} \mathrm{DBH}$ & 1.8 & $2.0(0.78)$ & 1.7 & $-9.5(0.13)$ & 2 \\
\hline
\end{tabular}

\section{Statistical analysis}

Actual 2010 field data was compared with actual 2012 field data to evaluate the shortterm changes in forest composition and structure caused by EAB-induced ash mortality over the two year period. Following this, actual 2012 field data was compared with predicted 2012 results to evaluate the short-term EAB-induced changes predicted by FVS. A Wilcoxon's signed-rank test was used to test the hypothesis that there are no differences in median stem abundance and basal area parameters between actual 2010 , actual 2012, and predicted 2012 data $(\alpha=$ $0.05, \mathrm{n}=9$ ). Within the micro-plot data, a Wilcoxon's signed-rank test was also used to test for a median difference in seedling abundance between actual 2010 and actual 2012 field data $(\alpha=0.05, \mathrm{n}=9)$. All analyses were performed using $\mathrm{SAS}^{\circledR}$ V. 9.3.

\section{Results}

Two year woody vegetation changes

Five of the eight parameters measured differed between the 2010 and 2012 field surveys. Total ash stems and ash basal area de- creased significantly following $\mathrm{EAB}$ invasion (Tab. 1, 2010 actual vs. 2012 actual). The number of ash stems surveyed within the whole plots decreased $36 \%$, from 36 to 23 over the two year period, creating canopy gaps and influencing other parameters. The number of trees $>12.7 \mathrm{~cm}$ DBH decreased significantly, causing total basal area and basal area of overstory trees $>12.7 \mathrm{~cm} \mathrm{DBH}$ to also significantly decrease. Though not significant, there was a $35 \%$ decline in stem numbers (79 stems) in the lower strata $(<$ $12.7 \mathrm{~cm} \mathrm{DBH},<137 \mathrm{~cm}$ height - Tab. 2). This decline was largely driven by a significant $77 \%$ decrease in white ash, while Virginia creeper (Parthenocissus quinquefolia (L.) Planch.) stems significantly increased by $136 \%$ (Tab. 2). Minor fluctuations in stem abundance of other species occurred within the lower strata, though none were significant.

\section{Predictive modeling} FVS modeling represents the predicted EAB-induced ash mortality; as expected, declines in the number of ash stems and ash
The $50 \%$ ash mortality rate applied in the

Tab. 2 - Short-term (2 year) changes in woody vegetation of the lower stratum $(<137 \mathrm{~cm}$ height) surveyed in 0.0004 ha micro-plots $(n=45)$ in forests in Franklin County, KY (USA) invaded by emerald ash borer. (a): Pre-establishment survey; (b): 2 year post-establishment survey.

\begin{tabular}{|c|c|c|c|c|c|}
\hline \multirow[t]{2}{*}{ Species } & \multicolumn{2}{|c|}{$\begin{array}{c}\text { Abundance } \\
\text { (stems/.002 ha) }\end{array}$} & \multirow[t]{2}{*}{ Change } & \multirow[t]{2}{*}{$\%$ Change } & \multirow{2}{*}{$\begin{array}{c}\text { Wilcoxon } \\
\mathrm{S}_{8}(\mathrm{P})\end{array}$} \\
\hline & $2010^{\mathrm{a}}$ & $2012^{b}$ & & & \\
\hline Total stems & 226.1 & 147.1 & -79 & -34.9 & $15.5(0.07)$ \\
\hline White ash & 117.8 & 26.9 & -90.9 & -77.2 & $20.5(0.01)$ \\
\hline Sugar maple & 29 & 10.9 & -18.1 & -62.4 & $13.0(0.08)$ \\
\hline Honeysuckle & 17.4 & 13.6 & -3.8 & -21.8 & $11.0(0.15)$ \\
\hline Virginia creeper & 14 & 33.1 & +19.1 & +136.4 & $-19.5(0.02)$ \\
\hline Red elm & 13.4 & 20.2 & +6.8 & +50.7 & $-11.5(0.19)$ \\
\hline Shagbark hickory & 9.4 & 9.7 & +0.3 & +3.2 & $4.0(0.66)$ \\
\hline
\end{tabular}


basal area were evident over the 2 year period (Tab. 1 - 2010 actual vs. 2012 predicted). Simulated declines in ash generated lower abundance and basal area predictions. FVS accurately predicted actual 2012 fores conditions (Tab. 1 - 2102 actual vs. 2012 predicted); none of the 2012 predictions of median stand basal area or stem density differed significantly from the actual median basal area and stem density surveyed in 2012. Importantly, the FVS predictions accurately estimated both the change in ash abundance and ash basal area. The number of actual ash stems in 2012 was $20 \%$ greater than FVS predictions, and actual 2012 ash basal area was $14 \%$ greater than predicted, but these differences were not significant.

\section{Discussion}

Short-term changes in forest structure following emerald ash borer invasion were caused primarily by a decrease in the number of overstory trees, with a corresponding reduction in total basal area, largely driven by widespread ash mortality. The loss of canopy trees results in formation of gaps that can lead to increased light reaching the forest floor, and can also alter moisture and temperature (Hubbell \& Foster 1986, Platt \& Strong 1989); loss of overstory ash is expected to generate similar outcomes (Gandhi \& Herms 2010a). Canopy disturbance may be correlated with increased establishment and growth of seedlings (Tubbs 1977). Ash seed germination requires stratification under moist conditions, but seedling development is optimized under sunny conditions (Schlesinger 1990). However, the total number of seedlings in our plots decreased by nearly $35 \%$ over the two year period, due to a significant decline $(77 \%)$ in ash seedlings. This sudden decrease could be attributed to seed production patterns of Fraxinus (Burns \& Honkala 1990). Yearly fluctuations in seed production and establishment often occur (Boerner \& Brinkman 1996). Seed production may have declined due to deteriorating health of trees of seed bearing age, and seedling regeneration may have declined due to depletion of the seed bank (Klooster et al 2014). Even though overstory ash died and canopy gaps were evident, we documented significant changes in only two of the six seedling species present over the two year period. It may take longer than two years to see changes in seedling regeneration of the remaining species in response to canopy openings, though we did observe a substantial $(>50 \%)$ but non-significant increase in red elm, U. rubra (Tab. 2), consistent with other studies in the USA Midwest (Flower et al. 2013a)

EAB-induced ash mortality caused significant changes over a short time period, and the southern variant of FVS accurately predicted those changes. In particular we focu- sed on four basic stand parameters (number of ash stems, ash basal area, total number of stems, total basal area) which we further divided into two size classes, and again FVS accurately estimated the parameters. While the eight parameters are clearly not independent, our approach provides a more thorough analysis of the model by exposing possible simulation errors between size classes. Simulations could accurately estimate total stem counts, but closer analysis within size classes could generate more useful predictions by estimating adult stem numbers versus sapling stem numbers; this information would be important for land managers. Similarly, although it is clear that basal area and stem density are not independent, they are both useful assessments of forest stands both ecologically and economically. It is important to evaluate whether FVS can accurately simulate both.

FVS uses regional variants that adjust growth and mortality equations to simulate how individual trees will react to tree decline and mortality; historically it has been used as a long term simulator. However, many catastrophic disturbance events, such as emerald ash borer and similar non-native invasions, occur very quickly and produce very drastic and rapid short term changes. Managers need a tool that can accurately simulate short term changes because of the rapid time frame in which ash mortality occurs. Our study covers a limited time period and the model predictions change in an expected manner. Yet, this analysis is an essential step for testing and introducing FVS for use within this system. Furthermore, these limitations do not take away from the future usefulness of FVS as a tool for aiding management decisions.

Land managers could use these simulations to develop a clearer understanding of how the loss of ash will impact and alter future forest dynamics. Managers could use this information to initiate operations to improve timber quality or wildlife resources in response to ash decline. We believe that the greatest potential use of FVS is as a platform used to simulate and compare potential management strategies in response to EAB invasion. Pre-emptive removal of ash, thinning operations, or no active management could be simulated in a given stand to evaluate impacts on timber improvement and/or wildlife resources. Similarly, chemical protection for all or certain subsets of ash could be simulated and subsequent effects on forest composition and structure evaluated. Managers could use this information to make more informed decisions based upon management goals.

Land managers can use FVS to simulate EAB-induced changes in forest composition and structure, but an estimated invasion date is needed to predict these short-term chan- ges. Approximately $50 \%$ of ash die by the fourth year following initial EAB invasion (Knight et al. 2013), but it is difficult to determine precise EAB invasion dates because few of the early signs are visible and evidence of establishment often begins in the canopy (Cappaert et al. 2005). Initial EAB invasion is estimated to be two years prior to the first sighting of exit holes or one year prior to the first positive trap catch (Knight et al. 2013). We used an initial invasion date of 2009 for our study, and chose a $50 \%$ ash mortality rate for the simulation based on suggested mortality rates (Knight et al. 2013). During this time $36 \%$ of ash within our plots died. Though our model's mortality was higher than the actual ash mortality, the model still produced an accurate projection of stand characteristics.

In spite of its effectiveness in simulating short-term EAB-induced forest changes within our stand, FVS does have limitations. FVS simulates growth and yield of established trees within forest stands, but is less effective projecting seedling development. Certain variants of FVS do include a full regeneration model, but the southern variant does not. Because of the stochastic nature of regeneration and very low survival rates of seedlings, regeneration data is often not incorporated into short term simulations (Radtke et al. 2011). For long term simulations regeneration must be added manually by using seedling data to implement future densities of established saplings (Dixon 2002). Furthermore, FVS is limited in how it applies natural mortality. The southern variant of FVS has no disease models and does not incorporate wind events in mortality calculations. Rather, mortality is calculated based on stand density, and once thresholds are crossed, mortality is applied based on an equation that compares tree height to stand height and is prioritized towards smaller trees (Dixon 2002). However, density limits can be adjusted and mortality manually applied to simulate natural events.

We tested the short term predictions of the southern variant of FVS on 9 plots within a singled forested area of central Kentucky. While the southern variant was developed using data from all 13 states within the region to calibrate growth and mortality models to local areas, these short-term predictions clearly need further testing. However, FVS is used extensively to predict forest stand dynamics by government agencies such as the USDA Forest Service and USDI Bureau of Land Management (Dixon 2002); our analysis demonstrates the short term accuracy of FVS, thus aligning it with the rapid impacts of EAB invasion and making it a potential tool for invasive species management in the southern region of the United States. 


\section{Conclusions}

Emerald ash borer-induced ash mortality is quickly changing the structure and composition of eastern North American forests. We evaluated a forest stand invaded by EAB and found that the southern variant of FVS accurately predicted short term changes in stem density and basal area parameters. Modeling and predicting forest changes are useful decision-making tools that can be used by managers and stakeholders. We argue that managers could use FVS to simulate potential management strategies in response to $\mathrm{EAB}$ invasion, and use other decision tools to help analyze these management options (Vannatta et al. 2012) and drive management decisions These tools can also be used to educate stakeholders about potential impacts of $\mathrm{EAB}$ invasion. Overall, EAB-induced ash mortality is quickly changing these forests and will ultimately alter how stakeholders manage their lands. Tools such as FVS can generate important information that could be used to guide management decisions in response to $\mathrm{EAB}$ invasion.

\section{Acknowledgments}

The authors thank Zac Helton, Jon Johnson, Adrienne Kinney, Melanie Sprinkle, and Sarah Wightman for field assistance, and three anonymous reviewers for helpful comments. This project was funded in part by the UDSA Forest Service FHP EM program and through funds provided by McIntire Stennis, and is published as Kentucky Agricultural Experiment Station publication number 1308-124.

\section{References}

Adkins JK, Rieske LK (2013). Loss of a foundation forest species due to an exotic invader impacts terrestrial arthropod communities. Forest Ecology and Management 295: 126-135. - doi: 10.1016/j.foreco.2013.01.012

Anonymous (2003). Natural resource information service (NRIS): field sampled vegetation (FSVeg) common stand exam (v. 1.5.1). Rocky Mountain Research Station, USDA Forest Service, Fort Collins, CO, USA, pp. 6.

Anulewicz AC, McCullough DG, Cappaert DL (2007). Emerald ash borer (Agrilus planipennis) density and canopy dieback in three North American ash species. Arboriculture and Urban Forestry 33: 338.

Aukema JE, Leung B, Kovacs K, Chivers C, Britton KO, Englin J, Frankel SJ, Haight RG, Holmes TP, Liebhold AM (2011). Economic impacts of non-native forest insects in the continental United States. PLoS One 6: e24587. - doi: 10.13 71/journal.pone.0024587

Bao T, Luo Y, Xu Z, Shi J, Liu Y (2008). Growth simulation of Fraxinus chinensis stands damaged by Hyphandria cunea in Beijing area. Forestry Studies in China 10: 60-63. - doi: 10.1007/ s11632-008-0001-2

Boerner RE, Brinkman JA (1996). Ten years of tree seedling establishment and mortality in an Ohio deciduous forest complex. Bulletin of the Torrey Botanical Club 309-317. - di: 10.2307/29 96780

Burns RM, Honkala BH (1990). Silvics of North America: Volume 2. Hardwoods. USDA Forest Service Agricultural Handbook 654, Washington, DC, USA, pp. 335.

Byers JE, Reichard S, Randall JM, Parker IM, Smith CS, Lonsdale WM, Atkinson IAE, Seastedt TR, Williamson M, Chornesky E, Hayes D (2002). Directing research to reduce the impacts of nonindigenous species. Conservation Biology 16: 630-640. - doi: 10.1046/j.1523-1739.2002. 01057.x

Cappaert D, McCullough DG, Poland TM, Siegert NW (2005). Emerald ash borer in North America: a research and regulatory challenge. American Entomologist 51: 152-165. [online] URL: http://www.nrs.fs.fed.us/pubs/jrnl/2005/nc_2005 cappaert_001.pdf

Coleman TW, Clarke SR, Meeker JR, Rieske LK (2008). Forest composition following overstory mortality from southern pine beetle and associated treatments. Canadian Journal of Forest Research 38: 1406-1418. - doi: 10.1139/X07-248

Dixon GE (2002). Essential FVS: a user's guide to the Forest Vegetation Simulator. Internal Report, Forest Management Service Center, USDA Forest Service, Fort Collins, CO, USA, pp. 209. [online] URL: http://biometrics.latech.edu/wpcontent/uploads/2013/03/EssentialFVS.pdf

EAB (2014). Home page. College of Agriculture, University of Kentucky, Lexington, KY, USA. [online] URL: http://pest.ca.uky.edu/EXT/EAB/ welcomeeab.html

Ehrenfeld JG (2010). Ecosystem consequences of biological invasions. Annual Review of Ecology, Evolution, and Systematics 41: 59-80. - doi: 10.1146/annurev-ecolsys-102209-144650

Emeraldashborer.info (2014). Home page. USDA Forest Service, Michigan State University, Purdue University, Ohio State University, USA. [online] URL: http://www.emeraldashborer.info

Faanes CA (1984). Wooded islands in a sea of prairie. American Birds 38: 3-6. [online] URL: https://sora.unm.edu/sites/default/files/journals/n ab/v038n01/p00003-p00006.pdf

Flower C, Knight K, Gonzalez-Meler M (2013a). Impacts of the emerald ash borer (Agrilus planipennis Fairmaire) induced ash (Fraxinus spp.) mortality on forest carbon cycling and successional dynamics in the eastern United States. Biological Invasions 15: 931-944. - doi: 10.1007/s105 30-012-0341-7

Flower CE, Knight KS, Rebbeck J, GonzalezMeler MA (2013b). The relationship between the emerald ash borer (Agrilus planipennis) and ash (Fraxinus spp.) tree decline: using visual canopy condition assessments and leaf isotope measurements to assess pest damage. Forest Ecology and Management 303: 143-147. - doi: 10.1016/j.for eco.2013.04.017

Flower CE, Long LC, Knight KS, Rebbeck J, Brown JS, Gonzalez-Meler MA, Whelan CJ (2014). Native bark-foraging birds preferentially forage in infected ash (Fraxinus spp. ) and prove effective predators of the invasive emerald ash borer (Agrilus planipennis Fairmaire). Forest Ecology and Management 313: 300-306. - doi: 10.1016/j.foreco.2013.11.030

Gandhi KK, Herms D (2010a). Direct and indirect effects of alien insect herbivores on ecological processes and interactions in forests of eastern North America. Biological Invasions 12: 389405. - doi: 10.1007/s10530-009-9627-9

Gandhi KJ, Herms DA (2010b). North American arthropods at risk due to widespread Fraxinus mortality caused by the alien emerald ash borer. Biological Invasions 12: 1839-1846. - doi: 10.10 07/s10530-009-9594-1

Haack RA (2006). Exotic bark- and wood-boring Coleoptera in the United States: recent establishments and interceptions. Canadian Journal of Forest Research 36 (2): 269-288. - doi: 10.1139/ x05-249

Haack RA, Jendek E, Liu H, Marchant KR, Petrice TR, Poland TM, Ye H (2002). The emerald ash borer: a new exotic pest in North America. Newsletter of the Michigan Entomological Society 47: 1-5. [online] URL: http://www.ncrs.fs. fed.us/pubs/jrnl/2002/nc_2002_Haack_001.pdf Hubbell SP, Foster RB (1986). Canopy gaps and the dynamics of a neotropical forest. In: "Plant ecology" (Crawley M ed). Blackwell, Oxford, UK, pp. 77-96.

Kennedy HE (1990). Green ash. In: "Silvics of North America (vol 2). Hardwoods" (Burns RM, Honkala BH). Agricultural Handbook 654, USDA Forest Service, Washington, DC, USA, pp. 348.

Klooster W, Herms D, Knight K, Herms C, McCullough D, Smith A, Gandhi KK, Cardina J (2014). Ash (Fraxinus spp.) mortality, regeneration, and seed bank dynamics in mixed hardwood forests following invasion by emerald ash borer (Agrilus planipennis). Biological Invasions 16 (4): 859-873. - doi: 10.1007/s10530-013-054 3-7

Knight K, Brown J, Long R (2013). Factors affecting the survival of ash (Fraxinus spp.) trees infested by emerald ash borer (Agrilus planipennis). Biological Invasions 15: 371-383. - doi: 10.1007/s10530-012-0292-Z

Martin AC, Zim HS, Nelson AL (1961). American wildlife and plants, a guide to wildlife food habits: the use of trees, shrubs, weeds, and herbs by birds and mammals of the United States. Courier Dover Publications, New York, USA, pp. 359.

Pimentel D, Zuniga R, Morrison D (2005). Update on the environmental and economic costs associated with alien-invasive species in the United States. Ecological Economics 52: $273-$ 288. - doi: 10.1016/j.ecolecon.2004.10.002 Platt WJ, Strong DR (1989). Treefall gaps and forest dynamics-Special Feature. Ecology 70: 535576. - doi: 10.2307/1940194

Radtke PJ, Herring ND, Loftis DL, Keyser CE (2011). Evaluating forest vegetation simulator predictions for Southern Appalachian upland hardwoods with a modified mortality model. 
Southern Journal of Applied Forestry 36: 61-70. - doi: 10.5849/sjaf.10-017

Rebek EJ, Herms DA, Smitley DR (2008). Interspecific variation in resistance to emerald ash borer (Coleoptera: Buprestidae) among North American and Asian ash (Fraxinus spp.). Environmental Entomology 37: 242-246. - doi: 10.16 03/0046-225X(2008)37[242:IVIRTE]2.0.CO;2

Reiners WA, Reiners NM (1970). Energy and nutrient dynamics of forest floors in three Minnesota forests. Journal of Ecology 58: 497-519. doi: $10.2307 / 2258286$

Schlesinger RC (1990). White ash. In: "Silvics of North America (vol 2). Hardwoods" (Burns RM, Honkala BH). Agricultural Handbook 654, USDA Forest Service, Washington, DC, USA, pp. 333.

Spaulding HL (2009). Forest of the future: simulating the effects of exotic invasive species on forest structure and composition. MS thesis, Department of Entomology, University of Kentucky, Lexington, KY, USA, pp. 99.
Spaulding HL, Rieske LK (2010). The aftermath of an invasion: structure and composition of Central Appalachian hemlock forests following establishment of the hemlock woolly adelgid, Adelges tsugae. Biological Invasions 12: 31353143. - doi: 10.1007/s10530-010-9704-0

Spaulding HL, Rieske LK (2011). A glimpse at future forests: predicting the effects of Phytophthora ramorum on oak forests of southern Appalachians. Biological Invasions 13: 1367-1375. doi: 10.1007/s10530-010-9895-4

Spurr SH (1962). A measure of point density. Forest Science 8: 85-96.

Straw NA, Williams DT, Kulinich O, Gninenko YI (2013). Distribution, impact and rate of spread of emerald ash borer Agrilus planipennis (Coleoptera: Buprestidae) in the Moscow region of Russia. Forestry 86: 515-522. - doi: 10.1093/ forestry/cpt 031

Tanis SR, McCullough DG (2012). Differential persistence of blue ash and white ash following emerald ash borer invasion. Canadian Journal of
Forest Research 42: 1542-1550. - doi: 10.1139/x 2012-103

Tubbs CH (1977). Natural regeneration of northern hardwoods in the northern Great Lakes region. Research Paper NC-150, North Central Forest Experiment station,USDA Forest Service, St. Paul, MN, USA, pp. 19. [online] URL: http:// digitalcommons.usu.edu/cgi/viewcontent.cgi?article $=8124 \&$ context $=$ aspen bib

Vannatta AR, Hauer RH, Schuettpelz NM (2012). Economic analysis of emerald ash borer (Coleoptera: Buprestidae) management options. Journal of Economic Entomology 105: 196-206. - doi: 10.1603/EC11130

Wharton ME, Barbour RW (1973). Trees and shrubs of Kentucky. University of Kentucky Press, Lexington, KY, USA, pp. 582.

Wilcove DS, Rothstein D, Dubow J, Phillips A, Losos E (1998). Quantifying threats to imperiled species in the United States. BioScience 48: 607615. - doi: $10.2307 / 1313420$ 